\title{
Polskojęzyczne opisy przypadku z zakresu psychiatrii i psychologii - model tekstowy czy wyjątek? Część II.
}

\section{Case reports in the field of psychiatry and psychology in Polish - a text model or an exception? Part II.}

\author{
Magda ŻELAZOWSKA-SOBCZYK \\ Uniwersytet Warszawski/ University of Warsaw \\ E-mail: magda.zelazowska@uw.edu.pl,
}

\author{
Magdalena ZABIELSKA \\ Uniwersytet im. Adama Mickiewicza/ Adam Mickiewicz University in Poznan \\ E-mail: mzabielska@wa.amu.edu.pl,
}

\begin{abstract}
The aim of this series of articles is to identify and characterize the main linguistic and structural features of medical case reports in the field of psychiatry and psychology. The series is divided into to two parts: theoretical and empirical. The main purpose of the first part is to present the theoretical background of the discourse of psychiatry and psychology, including the characteristics of case reports of these disciplines and instructions for authors for preparing this type of text, as well as the narrative approach, case conceptualization etc. The second part is an empirical one. The main research question is whether the case reports of psychiatry and psychology are typical representatives of the microgenre or whether they are different with respect to particular levels of the texts. The present authors focus on the structure of case reports and their rhetorical character - the way of presenting particular information and its linguistic representation. The psychiatric and psychological case reports will be compared with the case reports from clinical and surgical disciplines, for instance cardiology or otorhinolaryngology. The study presents both differences and similarities between the two types of case reports, which are illustrated with representative examples from the research material.
\end{abstract}

Keywords: medical communication, case report, case formulation, microgenre, psychology, psychiatry, narrative approach

\section{Wstęp}

Niniejsza praca stanowi kontynuację rozważań nad dyskursem psychiatryczno-psychologicznym, a w szczególności nad opisami przypadków medycznych z tych dziedzin. Pierwszy artykuł z cyklu opublikowany został w numerze 26/1. Jak już wcześniej wspomniano celem tegoż cyklu publikacji jest identyfikacja i charakterystyka dominujących cech na płaszczyźnie strukturalnej i lingwistyczno-retorycznej polskojęzycznych psychiatrycznych i psychologicznych opisów przypadków medycznych. W pierwszej, teoretycznej części cyklu przedstawione zostało szerokie tło literaturowe w zakresie dyskursu psychiatrii i psychologii, w tym też podejście narracyjne, 
obecność pacjenta w tekście oraz konceptualizacja przypadku jako jeden z ważniejszych elementów stawiania diagnozy psychiatrycznej i psychologicznej, ale też część składowa opisów przypadków. Celem niniejszego artykułu o charakterze empirycznym jest zestawienie opisów przypadków psychiatryczno-psychologicznych z opisami z dziedzin kliniczno-chirurgicznych (otorynolaryngologii i kardiologii), których przedmiotem badań jest pewien obszar ciała człowieka ( $\mathrm{tj}$. narząd słuchu i mowy, serce i układ krwionośny itd.). Głównym pytaniem badawczym jest określenie, na ile te, tworzące pewien wzorzec tekstów, cechy są modelowe - stałe, a w jakim stopniu determinowane przez dziedzinę medycyny i inne czynniki. Przyczynkiem do tak zakrojonych badań jest to, iż obecnie niewiele pozycji omawia zagadnienie psychiatrycznych opisów przypadków, szczególnie w takim świetle.

\section{Model tekstowy czy wyjątek?}

Materiał badawczy w niniejszym badaniu składał się z dwóch części, z których pierwsza obejmowała 15 psychiatrycznych i psychologicznych opisów przypadków z trzech czasopism specjalistycznych: Psychiatria, Psychiatria i Psychologia Kliniczna oraz Psychiatria Polska, opublikowanych w latach 2010-2019. Druga część składała się z 10 opisów przypadków z dziedzin chirurgiczno-klinicznych, opublikowanych w 2017 i 2018 roku w Nowej Audiofonologii i Polskim Przegladzie Otorynolaryngologicznym (czasopisma otorynolaryngologiczne) oraz w Chorobach Serca i Naczyń, Folia Cardiologica i Hematlogii (czasopisma kardiologiczne). Różnica w zakresie czasowym dwóch grup badawczych wynika z faktu, iż we wcześniejszych badaniach (zob. np. M. Żelazowska-Sobczyk 2019 oraz inne prace Autorek niniejszej publikacji) wykazano, iż opisy przypadków medycznych z dziedzin kliniczno-chirurgicznych posiadają w miarę stałą strukturę oraz sposób prezentowania informacji. W związku z tym wybrano tylko najnowsze opisy, aby zobrazować uzyskane wcześniej wyniki nowymi przykładami. Wybór czasopism oparto natomiast na czterech czynnikach: (1) publikowaniu treści w języku polskim ${ }^{1}$; (2) liczba punktów MNiSW²; (3) otwartym dostępie do artykułów oraz (4) regularnym publikowaniu opisów przypadków w danym tytule. Czynniki te spełniało niewiele czasopism, z których wybrano dalej te najbardziej reprezentatywne. Następnie Autorki dokonały wstępnej analizy publikowanych w tych latach opisów przypadków, wybierając z nich 15, które stanowią swoistą ilustrację badanego mikrogatunku. Warto nadmienić, iż w badaniu dotyczącym tytułów w polskojęzycznych opisach przypadków medycznych (M. Że-

\footnotetext{
${ }^{1} \mathrm{Z}$ obserwacji Autorek wynika, iż w ostatnich latach wiele czasopism polskojęzycznych rozpoczęło publikowanie artykułów wyłącznie w języku angielskim, mimo, iż początkowym językiem czasopisma był język polski. Jest to niejako odpowiedź na rosnące zapotrzebowanie publikacji w języku angielskim oraz skuteczny sposób promocji medycyny polskiej i nauki ogólnie za granicą. Z tego też powodu, wybór czasopism publikujących prace w języku polskim był ograniczony do kilku pozycji.

${ }^{2}$ Według wykazu czasopism naukowych MNiSW. (URL https://www.gov.pl/web/nauka/wykaz-czasopism-naukowych-zawierajacy-historie-czasopisma-z-publikowanych-wykazow-zalata-2013-2016). [Pobrano dostęp 18.02.2019].
} 
lazowska-Sobczyk/ M. Zabielska 2018) Autorki zaobserwowały, iż wyrażenie „studium przypadku/ów" stosowane jest częściej w opisach przypadków w psychiatrii i psychologii, np. w czasopiśmie Psychiatria Polska ${ }^{3}$.

Wybrane opisy z dwóch grup analizowano i porównywano na dwóch płaszczyznach: strukturalnej (budowa opisów) i retoryczno-lingwistycznej, tj. jako wzorce prowadzenia wywodu, czyli sposób prezentowania informacji w tekście. W swojej monografii M. Żelazowska-Sobczyk (2019) przedstawiła wyniki analizy otorynolaryngologicznych opisów przypadków, adaptując model prowadzenia wywodu w artykułach naukowych K. Nwogu (1990) oraz J. Swalesa (1990) do określenia warstwy retorycznej (zawartość treściowa, prowadzenie wywodu) w opisach przypadków medycznych (zob. M. Żelazowska-Sobczyk 2019: 141-1714). Wnioski z tych rozważań, tj. zaadaptowany model, stał się podstawą analizy tradycyjnych opisów przypadków oraz niejako bazą do analizy opisów psychiatrycznych. Autorki uzyskały następujące wyniki, które zostały przedstawione poniżej i zobrazowane odpowiednimi przykładami z materiału badawczego.

Na początku warto zwrócić uwagę, iż już po wstępnej analizie materiału zauważono, że tradycyjne opisy przypadków i opisy psychiatryczne mają zbliżoną strukturę - zawierają Wstęp, Opis przypadku (w psychiatrycznych opisach często podzielony jeszcze na podsekcje w celu lepszej prezentacji informacji), Omówienie i ewentualnie Wnioski. Istotne różnice zaobserwowano w drugiej sekcji, czyli sposobie opisu pacjenta, wywiadu rodzinnego i kontekstu leczenia (np. środowisko społeczne), przeprowadzonych badań, podjętego leczenia, jego wyników itp., dlatego właśnie analiza tej części będzie najobszerniejsza. W przypadku pozostałych sekcji Autorki ograniczą się tylko do krótkiej charakterystyki i podania reprezentatywnych przykładów.

Opisy przypadków rozpoczynały się od tytułu w języku polskim i angielskim oraz abstraktu w języku angielskim lub abstraktu w jęz. angielskim i streszczenia w jęz. polskim. Występowały tu zarówno abstrakty/streszczenia w formie ciągłej, jak i strukturalnej. Ze względu na liczbę analizowanych tekstów, elementy te nie będą dalej omawiane, gdyż uzyskane wyniki na takiej próbce tekstów nie wykazałyby charakterystycznych dla tych elementów tendencji.

Kolejnym elementem był Wstęp, który w obu typach tekstów zawierał podobne zakresy informacji, które podzielić można na trzy kroki (ang. moves według K. Nwogu 1990, 1991, 1997 i J. Swalesa 1990). Krok 1 to Ustalenie terytorium, realizowane poprzez przedstawienie tła problemu, które dokonuje się za pomocą podania następujących informacji tj.: (a) definicja problemu, (b) dokładny opis omawianego zagadnienia (choroby, zaburzenia itp.), (c) rys historyczny. W celu ukazania różnicy lub podobieństw między dziedzinami kliniczno-chirurgicznymi oraz psychiatrią

\footnotetext{
3 Tendencja ta nie jest jednak widoczna w analizowanych pracach, prawdopodobnie ze względu na niewielką próbkę tekstów.

${ }^{4} \mathrm{~W}$ pracy Autorka omawia opisy przypadków w języku angielskim i polskim w ujęciu konfrontatywnym na czterech płaszczyznach: strukturalnej, retorycznej (jako wzorce prowadzenia wywodu), metadyskursywnej oraz lingwistycznej. W niniejszej publikacji zostan ą przywołane tylko niektóre z ważniejszych wyników dot. struktury i modelu prowadzenia wywodu.
} 
i psychologią, najpierw zostanie podany przykład z dziedzin pierwszych, a następnie z opisów psychiatrycznych.

(a) Nazwa MELAS jest akronimem powstałym z określeń najczęściej występujących objawów tego zespołu - myopathy (miopatia), encephalopathy (encefalopatia), lactic acidosis (kwasica mleczanowa), stroke-like episodes (epizody udaropodobne). [...] (c) Zespół MELAS został po raz pierwszy opisany w 1984 r. przez Pavlakisa i wsp. [2]. [...] Choroby związane z mutacjami mitochondrialnego DNA przekazywane są przez matkę wszystkim potomkom, zarówno żeńskim, jak i męskim. (NA1)

(a) Zespół Aspergera (ZA) należy do całościowych zaburzeń rozwojowych, nazywanych także zaburzeniami ze spektrum autyzmu (autism spectrums disorders, ASD). [...] (c) Do tej pory, według klasyfikacji DSM-IV, pacjentom z zaburzeniami autystycznymi stawiano jedną z pięciu diagnoz [...]. (b) Wiele osób z ZA ma iloraz inteligencji na poziomie przeciętnym albo powyżej niego. (PPK1)

(a) Choroba Whipple'a jest przewlekłą, układową, wielonarządową chorobą infekcyjną [1-3]. [...] (c) Po raz pierwszy choroba została opisana pod nazwą lipodystrofii jelitowej w 1907 roku przez George'a Hoyt Whipple'a [...]. (b) Czynnikiem etiologicznym choroby Whipple'a jest Gram-dodatnia pałeczka Tropheryma whippelii przypominająca wyglądem prątek gruźlicy [...]. (PP3)

Krokiem 2 jest Ustanowienie niszy, który realizowany jest przez (d) wskazanie rzadkości problemu oraz (e) odwołanie się do aktualnej wiedzy i dostępnej, odnośnej literatury.

(d) Ze względu na dużą różnorodność, zarówno od strony klinicznej, jak i histologicznej, często stanowią poważny problem diagnostyczny, co skutkuje późnym rozpoznaniem. (PPO1)

(e) Dotychczas w literaturze przedmiotu opisano pojedyncze przypadki pacjentów z zespołem Kostmanna, raportując sposób i efektywność leczenia stanu zapalnego ucha środkowego i/lub następczego ostrego stanu zapalnego wyrostka sutkowatego. (NA2)

(d) Choroba Whipple'a jest schorzeniem rzadkim, dotyczącym $0,01 \%$ populacji, mimo, że liczbę bezobjawowych nosicieli bakterii w ślinie i jelitach szacuje się na 3-5\% [11,12]. [...] Obraz kliniczny choroby Whipple' a jest mało charakterystyczny. Zwłaszcza początek bywa identyczny z innymi chorobami przewodu pokarmowego. (PP3)

(e) Kryteria identyfikacji zaburzeń należących do ASD są jednak kontrowersyjne i dzielą ekspertów. Molloy i Vasil uznają zespół Aspergera za odmienność neurologiczną, z której obecne oczekiwania społeczne uczyniły zaburzenie ${ }^{(9)}$. [...] (PPK1)

Ostatni krok - 3 - tj. Zajęcie niszy, realizowany jest poprzez (f) opis proponowanej metody leczenia i (g) odwołanie się do omawianego przypadku i/lub określenie celu pracy.

(f) Są bardzo agresywne, w związku z czym leczenie ich powinno opierać się na chirurgicznym usunięciu zmiany z marginesem zdrowych tkanek, ewentualnym wycięciu węzłów chłonnych szyi oraz na leczeniu uzupełniającym (radio- i chemioterapia) $[9,10,11]$. (PPO1) 
(g) W pracy przedstawiono opis skutecznej chemioterapii indukująco-konsolidującej u 20letniej chorej na APL, która ze względów religijnych nie wyrażała zgody na przetaczanie preparatów krwiopochodnych. (HM1)

$* * *$

(f) Zalecaną terapią w chorobie Whipple'a jest parenteralne podanie antybiotyku przenikającego barierę krew-mózg [...], a następnie 12-miesięczne doustne leczenie trimetoptimem/sulfamrtoksazolem (2 x 1 tabl. a $960 \mathrm{mg}$ ) [5]. (PP3)

(g) Zainteresowanie autorów wzbudził nietypowy przebieg EW [leczenie elektrowstrząsowe] u młodej kobiety [...]. Prawdopodobnie jest to pierwsze doniesienie opisujące przypadek wystąpienia jako powikłania leczenia EW urojeń odnoszących, prześladowczych i onirycznych oraz omamów węchowych. (PP2)

Jak widać na powyższych przykładach, Wstęp w opisach z dziedzin kliniczno-chirurgicznych oraz psychiatrii i psychologii są podobne, zawierają tożsame informacje, tj. zarys problemu i jego definicję, rys historyczny, wskazanie nietypowości i rzadkości opisywanego zagadnienia, odwołanie się do odnośnej literatury i innych podobnych badań, wskazanie proponowanej metody leczenia oraz zarys opisywanego przypadku. Warto tu jednak zauważyć, iż Wstęp w opisach psychiatrycznych i psychologicznych był często o wiele dłuższy niż z dziedzin kliniczno-chirurgicznych. Często to właśnie Wstęp stanowił pole do dyskusji, a dopiero potem zostawał wprowadzony przypadek (np. PSYCH2). W jednym z artykułów z czasopisma Psychiatria (PSYCH1), cały artykuł składał się tylko z jednej sekcji - ze Wstępu, jednak wyróżnić tu możemy zarówno informacje zwykle występujące we Wstępie, Opisie przypadku i Omówieniu/Dyskusji oraz Wnioski.

Sekcja Opis przypadku stanowi główną część opisów przypadków z zakresu psychiatrii i psychologii. Jest to szczegółowy opis pacjenta i jego szeroko rozumianego środowiska. To właśnie w tej sekcji dostrzec możemy najwięcej elementów różniących opisy przypadków z psychiatrii i psychologii oraz z dziedzin kliniczno-chirurgicznych. Warto się tu odwołać do wcześniej opisanych wytycznych, publikowanych w literaturze anglojęzycznej na temat konceptualizacji przypadku (sformułowania), w celu zbadania, na ile te wytyczne mogą mieć zastosowanie i przełożenie na polskie opisy. Warto tu więc przypomnieć, zawarcie jakich elementów ${ }^{5}$ J. Virués-Ortega i R. Moreno-Rodriguez (2008) uważają za zalecane przy tworzeniu opisu przypadku z zakresu psychologii i psychiatrii.

1. Charakterystyka pacjenta i powód zgloszenia do specjalisty, w tym dane pacjenta - wiek, płeć i inne cechy osobiste, wykształcenie, zawód, informacje o środowisku kulturowym, rodzinie oraz obecne i przebyte choroby/diagnozy/leczenie, przyjmowane obecnie leki.

2. Strategie oceny czyli opis stosowanych metod oceny pacjenta.

3. Konceptualizacja przypadku, rozumiana jako pewne szczegółowe wyjaśnienie terapeuty - co jest problemem, dlaczego, jaki kształt to przybrało i co można z tym zrobić.

\footnotetext{
${ }^{5}$ J. Virués-Ortega i R. Moreno-Rodriguez (2008) proponują, aby były to osobne sekcje, jednak w polskojęzycznych opisach przypadków z zakresu psychologii i psychiatrii informacje te zawarte są raczej tylko w dwóch sekcjach: Opis przypadku i Omówienie/Dyskusja.
} 
4. Leczenie, $\mathrm{tj}$. opis różnych typów leczenia, pasujących do przedstawionego przypadku wraz z czynnikami związanymi z leczeniem, np. osoba samego terapeuty.

5. Wybór leczenia, czyli uzasadnienie wybranego typu leczenia.

6. Zastosowanie leczenia - opis odbytych sesji terapeutycznych.

7. Czynniki zwiazane z osoba terapeuty.

8. Projekt badania, tj. określenie sposobu zaprojektowania planu badania lub obserwacji pacjenta.

9. Analiza danych, rozumiana jako przedstawienie uzyskanych danych z poszczególnych sesji.

10. Efektywność $i$ wydajność interwencji, zawierająca najważniejsze wyniki leczenia wraz z krótkim opisem stanu po leczeniu.

Poniżej przedstawione zostaną przykłady, w jaki sposób powyższe informacje wplatane są $\mathrm{w}$ opis pacjenta $\mathrm{w}$ języku polskim. W celu porównania opisów polskojęzycznych z zakresu dziedzin kliniczno-chirurgicznych oraz psychiatrii i psychologii, Autorki przytoczą najpierw przykłady z pierwszych dziedzin - otorynolaryngologii i kardiologii, w których wzorzec prowadzenia wywodu oparty jest na schemacie kroków, a następnie przytoczą przykłady z opisów psychiatryczno-psychologicznych.

W sekcji Opis przypadku w tradycyjnym modelu ${ }^{6}$ realizowanych jest pięć kroków. Krok 4 czyli Prezentacja przypadku, wraz z (h) wstępną charakterystyką i dominującą dolegliwością oraz stan pacjenta przy przyjęciu do szpitala; (i) informacją o środowisku społecznym i zawodowym oraz trybie życia pacjenta; (j) historią choroby i krótkim (!) wywiadem lekarskim; (k) wywiadem rodzinnym oraz (l) historią przyjmowanych leków. Krok 5 to Prezentacja przeprowadzonych badań wraz ze (m) wstępną diagnozą; (n) opisem badań diagnostycznych; (o) opisem testów laboratoryjnych; (p) opisem testów genetycznych; (r) opisem dodatkowych konsultacji lekarskich oraz (s) diagnozą końcową. Punkty $(\mathrm{k}),(\mathrm{m}),(\mathrm{p}) \mathrm{i}(\mathrm{r})$, zaczerpnięte z zaadaptowanego przez M. Żelazowską-Sobczyk (2019) modelu, nie występowały w analizowanych opisach w ramach niniejszego badania, pojawiały się jednak w analizowanych wcześniej tekstach (patrz ww. monografia). Krok 6 stanowi Opis metod leczniczych, $\mathrm{tj}$. zastosowanego leczenia (t) operacyjnego; (u) farmakologicznego; (w) przebiegu operacji oraz (x) zastosowanych narzędzi. Krok 7 omawia Wyniki leczenia, w tym (y) brak komplikacji śródoperacyjnych; (z) stan pooperacyjny; (aa) kontynuację leczenia; (ab) stan przy wypisie oraz dalsze zalecenia lekarskie i (ac) badania kontrolne wraz z opisem stanu pacjenta po leczeniu. Ostatnim krokiem jest krok 8, opisujący Trudności diagnostyczno-kliniczne, w tym (ad) komplikacje śródoperacyjne.

(h) Pacjentka była diagnozowana na początku sierpnia 2016 roku w Klinice Hematologii [...] z powodu narastającego osłabienia, zawrotów głowy, nawracających krwawień z nosa i obserwowanej w morfologii krwi pancytopenii. (HM1)

\footnotetext{
${ }^{6} \mathrm{~W}$ rozumieniu dziedzin kliniczno-chirurgicznych.
} 
(i) W wywiadzie stwierdzono, że chora nie pali od 15 lat, na co dzień dość dobrze toleruje wysiłek, wiedzie spokojne i dostatnie życie u boku męża oraz ma pełne wsparcie rodziny. (CSN2)

(j) Ponadto ustalono, że choruje on na łuszczycę, dnę moczanową i upośledzenie umysłowe w stopniu umiarkowanym i z tego powodu nie ustalono jednoznacznie czasu pojawienia się dolegliwości. (PPO2)

(1) W dokumentacji medycznej pacjentki były odnotowane częste i samowolne zmiany dawek przyjmowanych beta 2 -mimetyków. (CSN2)

(n) W badaniu przedmiotowym otoskopowo stwierdzono błony bębenkowe zachowane, przezierne. Wykonano badania audiometryczne - audiometrię tonalną, tympanometrię, badanie odruchów z mięśnia strzemiączkowego oraz badanie otoemisji akustycznych (TEOAE). (NA1)

(o) W morfologii krwi obwodowej przy przyjęciu stwierdzono liczbę WBC 12,8 G/l, stężenie $\mathrm{Hb}$ 6,2 g/dl, liczbę PLT 7 G/l. (HM1)

(s) Na podstawie wyników ABPM, OBPM i HBPM rozpoznano AH. (FC1)

(t) Pacjenta przekazano na oddział kardiochirurgii, gdzie z zastosowaniem krążenia pozaustrojowego implantowano protezę mechaniczną SJM Regent $23 \mathrm{~mm}$ w pozycję aortalną. (CSN1)

(u) Włączono leczenie farmakologiczne - metyldopę w dawce $500 \mathrm{mg} /$ dobę oraz kwas acetylosalicylowy w dawce $75 \mathrm{~g} /$ dobę. (FC1)

(w) Podczas zabiegu stwierdzono guz części chrzęstnej przewodu, blokujący jego światło. Zmianę usunięto w całości, z podwójnego dostępu (wewnątrzusznego i zausznego) z marginesem zdrowych tkanek. Nie stwierdzono naciekania kości. (PPO1)

(x) Rozległa jama pooperacyjna wymagała użycia do tamponady 8 opatrunków typu „,Merocel” oraz 2 setonów z gazy, założono także tamponadę tylną cewnikiem Folley'a. (PPO2)

(y) Nie odnotowano komplikacji podczas obydwu zabiegów. (NA1)

(z) Pacjent przebył zabieg bez powikłań w okresach około- i pooperacyjnym. (CSN1)

(aa) W pooperacyjnym badaniu histopatologicznym stwierdzono ceruminous adenocarcinoma (guz usunięty w granicach zdrowych tkanek). Pacjentkę skierowano na uzupełniającą radioterapię. Podczas leczenia napromienianiem obserwowano wycieki z ucha, które ustąpiły po leczeniu zachowawczym. (PPO1)

(ab) W 7. dobie po zabiegu chory został wypisany do domu w dobrym stanie ogólnym. (CSN1)

(ac) Podczas 6-letniej obserwacji nie nastąpił nawrót choroby. W badaniu echokardiograficznym utrzymywała się prawidłowa kurczliwość serca, zmiany w zapisie EKG wycofały się w 12. miesiącu obserwacji. (FC2)

(ad) Podczas bezpośredniej chirurgicznej inspekcji natywnej zastawki stwierdzono stary ropień zlokalizowany w obrębie pierścienia zastawki; podczas usuwania płatka prawowieńcowego doszło do otwarcia ropnia — treść ropną w całości usunięto, a pierścień przepłukano roztworem betadyny. (CSN1) 
Jak widać na powyższych przykładach tradycyjny wzorzec prowadzenia wywodu w sekcji Opis przypadku prowadzi czytelnika od momentu zgłoszenia się pacjenta do szpitala (opisując stan pacjenta i dolegliwości, wywiad rodzinny i historię choroby), poprzez opisy wyników przeprowadzonych testów diagnostycznych i laboratoryjnych, zastosowanego leczenia operacyjnego i farmaceutycznego do określenia stanu pacjenta po leczeniu oraz wskazania możliwych komplikacji w całym procesie leczenia. Dostrzegamy tu skupienie się szczególnie na czynnościach i dokładnych opisach objawów i wyników (stosując konstrukcje bezosobowe, np. „W maju 2016 r. ponowiono próbę wszczepienia implantu [...] (NA2), odsuwając osobę pacjenta na dalszy plan. Jak pokazują badania nad obecnością pacjenta w medycznych opisach przypadków (np. M. Murawska 2014; M. Zabielska/ M. Żelazowska 2016) osoba pacjenta sprowadzona jest tylko do kilku wyrażeń „,pacjent”, ,pacjentka”, ,kobieta”, „,mężczyzna” itp. np. „Do kliniki przyjęto 58-letnią kobietę [....]” (PPO1), „U 49-letniego chorego w 1999 roku rozpoznano MDS pod postacią opornej na leczenie niedokrwistości [...]” (HM2), „Pacjentka w wieku 40 lat, wcześniej nieleczona przewlekle, w 23. tygodniu pierwszej ciąży trafiła do poradni kardiologicznej [...]" (FC1) itd.

W psychiatrycznych i psychologicznych opisach przypadków sekcja Opis przypadku jest o wiele dokładniejsza oraz skupia się w znaczącym stopniu na pacjencie, jego uczuciach, myślach, obawach, zachowaniu, opowieściach, historiach rodzinnych, historii choroby itd.

W analizowanych opisach przypadków z zakresu psychiatrii i psychologii, Autorki niniejszej pracy, na postawie wytycznych J. Virués-Ortegi i R. Moreno-Rodrigueza (2008) oraz American Psychological Association wyróżniły następujące informacje, często podawane w różnej kolejności, w zależności od autorów, opisywanego zagadnienia, konstrukcji pracy itp.

(1) Wstępna charakterystyka pacjenta (powód przyjęcia do szpitala i stan pacjenta przy przyjęciu, płeć, wiek, główne cechy itp.)

Pacjentka, obecnie 19-letnia, w wieku 14 lat zgłosiła się z matką do poradni zdrowia psychicznego dla dzieci z powodu natrętnych myśli, problemów z jedzeniem, izolacji społecznej oraz infantylnego zachowania. (PPK1)

Mężczyzna, lat 39, z wyższym wykształceniem. Dwa lata wcześniej uległ wypadkowi komunikacyjnemu, w którym doznał obrażeń wielonarządowych i wstrząsu krwotocznego. W wyniku utraty krwi u chorego doszło do rozwoju hipoksji skutkującej poważnym niedotlenieniem mózgu. (PPK3)

Pacjentka: 55 lat, panna, bezdzietna, wykształcenie średnie, leczona z powodu schizofrenii paranoidalnej (według ICD-10) od 23. roku życia, całkowicie ubezwłasnowolniona (opiekunem prawnym jest jej brat). (PP1)

54-letni pacjent, z wyższym wykształceniem, żonaty, jedno dziecko (dorosły syn), do maja 2010 roku pracownik banku, aktywny zawodowo do początku 2013 roku, aktualnie rencista, bez obciążeń rodzinnych chorobami psychicznymi i neurologicznymi. Przyjęty do Kliniki [...] w celu diagnostyki pogarszającego się od około 1,5 roku stanu ogólnego [...]. (PP3) 
Pan B. był młodym mężczyzną. Pracował na wysokim stanowisku, dobrze zarabiał. Miał liczne osiągnięcia edukacyjne - ukończył dwa fakultety, z sukcesem startował w licznych konkursach, jego życie zawodowe było historią sukcesu. [...] Jednocześnie w życiu Pana B. panowała pustka. (PSYCH1)

Kobieta 72-letnia, wdowa, matka zdrowej córki (mieszkającej w USA), babcia trzech nastolatków bez zaburzeń psychicznych. (PSYCH3)

\section{(2) Wywiad rodzinny}

\section{(2a) Ciąża, narodziny, okres noworodkowy}

Z wywiadu zebranego od matki wiadomo, że pacjentka jest dzieckiem z C III [...]; poród siłami natury w 40. tygodniu, waga urodzeniowa $3900 \mathrm{~g}$ [...]. (PPK1)

Pierwszy, z powodu cech niedotlenienia, spędził jeden dzień w inkubatorze. [...] [Bliźnięta] okazały się bardzo żywotne i płaczliwe, stosunkowo mało spały. (PPK2)

Pani M. urodziła się w 37. tygodniu ciąży (3 ciąża, 3 poród), poród odbył się siłami natury. W skali APGAR otrzymała 10 punktów. Rozwój pacjentki przebiegał prawidłowo. (PSYCH4)

\section{(2b) Żłobek, przedszkole, szkoła, wykształcenie, zawód}

Od 4. roku życia uczęszczała do przedszkola, gdzie wykazywała mniej trudności adaptacyjnych. [...] Jako sześciolatka poszła do klasy „0”, od początku bardzo angażowała się w naukę. [...] Uczyła się bardzo dobrze (średnia ocen 5,6) i chętnie. Jej zachowanie w szkole oceniano jako wzorowe. (PPK1)

W IV klasie pojawiły się pierwsze kłopoty wychowawcze, manifestujące się głównie w szkole. [...] a starszego nauczyciele odbierali jako złośliwego. Traktował słyszane komunikaty dosłownie: „Nauczycielka mówiła: »Wyjmijcie wszystko z tornistrów«, a on wysypywał zawartość torby na ławkę". (PPK2)

Od trzeciego roku życia bracia uczęszczali do przedszkola, wcześniej zajmowała się nimi matka (prowadząca ośrodek wypoczynkowy) wraz z innymi, przygodnymi osobami, które ich rozpieszczały. (PPK2)

Opowiadał, jak mimo nacisków kolegów, udawało mu się unikać sytuacji towarzyskich, na przykład w liceum został zmuszony do udziału w klasowych Mikołajkach. (PSYCH1)

\section{(2c) Dojrzewanie i relacje seksualne}

Pacjentka dostrzega zachodzące u siebie zmiany biologiczne, pojawienie się popędu seksualnego. Wykazuje typowe dla okresu adolescencji zainteresowanie płcią przeciwną, co wyraża w poniższych wypowiedziach: [...] ,a jeszcze pojawiają się emocja, jak ktoś rączkę dotknie, czy poklepie, popatrzy się oczkami w oczka [...] i są jeszcze takie różne odczucia i nie wiemy, co z tym zrobić, a nawet myślimy, że to będzie rodzinka i może potomek". (PPK1)

Wystąpił wtórny brak miesiączki. [...] Kolegów poza szkołą nie miała, wzbudzała zainteresowanie chłopców, oni byli jej jednak obojętni. Zaprzeczyła kontaktom seksualnym. (PSYCH4) 


\section{(2d) Środowisko rodzinne (czlonkowie rodziny, ich krótka charakterystyka)}

Rodzina pacjentki składa się z czterech osób. Matka ma 46 lat, od 8 lat wyjeżdża w celach zarobkowych do Anglii. [...] (PPK1)

Decyzję o rozstaniu [rozwodzie] podjął mąż, po przebyciu zawału serca. Poinformował o tym żonę dwa tygodnie po śmierci jej terminalnie chorej matki, będącej wcześniej pod jej opieką. Kobieta nie radziła sobie wówczas z sytuacją, przebywała na zwolnieniu lekarskim, leczyła się z powodu depresji. (PPK2)

We wrześniu 2006 roku poznał przez Internet kobietę, z którą zaczął utrzymywać kontakt online, a następnie spotykać się. [...] Kobieta, z którą zamieszkał, podawała, iż posiada podwójne obywatelstwo: polskie i francuskie, i że jej były mąż jest szefem mafii narkotykowej. [...] Wielokrotnie prowadziła w obecności pacjenta rozmowy telefoniczne, planowała spotkania z różnymi osobami, według niej ,wplątanymi w aferę narkotykową”. [...] W trakcie trwającego 4 lata związku kilkakrotnie twierdziła, że jest w ciąży, jednak po kilku miesiącach informowała partnera, że poroniła. (PPK5)

Pochodzi [pacjentka] z rodziny wielodzietnej. Starszy brat (33 lata) z zawodu jest informatykiem, starsza siostra (31 lat) ukończyła szkołę muzyczną. Ma dwójkę młodszego rodzeństwa, braci w wieku 21 i 13 lat. Mieszka w domu z rodzicami i dwójką młodszego rodzeństwa. Matka pacjentki z zawodu jest księgową, ojciec był strażakiem, obecnie przebywa na emeryturze. To właśnie ojciec zajmuje się domem, pod nieobecność matki. W rodzinie brak jest obciążeń chorobami psychicznymi. Swoją rodzinę pani M. określiła jako „kochającą, wspierającą”. (PSYCH4)

\section{(2e) Narracja członków rodziny}

Matka określa siebie jako osobę wrażliwą, ,przejmującą się”. [...] Matka opisywała córkę jako wrażliwą, delikatną, przejmującą się tym, że ktoś coś powie na jej temat [...]. (PPK1)

Z relacji córki wynika, że przez wczesne dzieciństwo oraz okres dojrzewania obserwowała u matki częste zmiany obrazu psychopatologicznego i wspomina to w następujących słowach: „miałam dwie mamy - jedną aktywną, wesołą, uśmiechniętą, a drugą - bierną i smutną". (PSYCH3)

\section{(2f) Predyspozycje genetyczne/rodzinne}

Poza tym kuzyn ze strony matki był w przeszłości leczony psychiatrycznie i zwolniony z tego powodu z obowiązku służby wojskowej. „Ma opinię ekscentryka”. (PPK2)

$\mathrm{W}$ rodzinie pochodzenia pacjentki nikt nie chorował na zaburzenia psychiczne. (PSYCH3)

\section{Zachowanie pacjenta $w$ różnych środowiskach}

\section{(3a) Obserwacje zachowania (w tym narracja pacjenta o swoich dolegliwościach)}

Chodziła przygarbiona, małymi kroczkami. „Mam problem z osobowością i kontaktami z rówieśnikami mówiła" - mówiła. [...] Nadal utrzymywały się natrętne myśli, myśli samobójcze („Mam takie myśli, żeby skoczyć ze skały”). Podawała, że śnił jej się własny pogrzeb, na którym byli obecni lekarz prowadzący i psycholog. (PPK1)

Pacjentka była ambiwalentna w ocenie swoich zachowań. Relacjonowała, że od dawna podejrzewała u siebie ,chorobę dwubiegunową”, że od co najmniej czterech lat obserwuje 
u siebie wahania nastroju - od stanów „,depresji” z uczuciem smutku, wyczerpania, anhedonii, nadmierną senność, znacznym spadkiem aktywności, myślami samobójczymi do stanów „euforii”, „hiperaktywności”, gdy nadrabia powstałe w poprzednich okresach zaległości [...]. (PPK4)

Pewnego dnia po wynikach rekrutacji wyszła z domu, a gdy po kilku godzinach nie wróciła, zaniepokojona matka przeszukała jej pokój i znalazła kartkę z prośbą ,aby nie chować jej na pobliskim cmentarzu" [...]. (PSYCH4)

\section{(3b) Stan psychiczny}

W obszarze psychologicznym (intraspychicznym) pacjentka prezentuje własne przekonania na temat życia i związanych z nim zmian. (PPK1)

W rozmowie jest hiponimiczny. Wszystkie wypowiedzi interpretuje dosłownie. Nie potrafi sprecyzować, czym się interesuje, a na pytanie, co lubi robić, odpowiada: „Jeść mięso, na przykład z dzika". (PPK2)

W badaniu psychiatrycznym pacjentka prawidłowo zorientowana autopsychicznie i częściowo allopsychicznie (nie potrafi podać dokładnej daty - dnia miesiąca). (PP1)

\section{(3c) Kontakty społeczne}

W obszarze społecznym (interakcyjnym) znaczący jest brak relacji z rówieśnikami. (PPK1)

W trakcie rozwodu rodziców starszy z braci zaczął coraz gorzej funkcjonować społecznie. (PPK2)

Jak wspomniano, Pan B. w zasadzie nie utrzymywał kontaktów towarzyskich. [...] Pan B. był przekonany, że żaden związek nie może mu się udać, więc starał się ograniczać swoje zainteresowanie do minimum. (PSYCH1)

W trakcie wizyty pacjent poruszał temat odrzucenia społecznego, ale w odmiennym kontekście - zmienił się rodzaj zagadnień poruszanych w trakcie rozmowy. Pacjent zaczął mówić na temat potrzeby nawiązania relacji z rówieśnikami na uczelni, na której studiuje, a nie uporczywie skarżyć się na ból związany z przeszłymi wydarzeniami ${ }^{7}$. (PSYCH2)

\section{(3d) Uczucia pacjenta}

„Julcia wierzy, że Pani [terapeuta] wszystko zrozumie i będzie Pani miała wiedzę dużą na tyle, by wiedziała już Pani wszystko o Julci. Tylko Julcia bardzo boi się o wszystkim powiedzieć, bo Julcia nieraz próbowała i nie mogła Julcia przełamać w sobie tego wstydu, skrępowania i lęku”. (PPK1)

\section{Przebyte choroby/leczenie, wcześniejsze diagnozy}

\section{(4a) Historia chorób}

Rozpoznano zespół Aspergera. (PPK1)

\footnotetext{
${ }^{7}$ Zachowano oryginalne formatowanie, tj. wyróżnienie (pogrubienie) fragmentów tekstu.
} 
Podczas pobytu [w sanatorium] zostały zbadane psychologicznie. [...] Młodszy z braci „potrafi dłużej bawić się określonymi elementami, wielokroć powtarza te same lub inne czynności - bawi się jakby sam ze sobą". (PPK2)

Badanie wykazało obecność komórek nabłonka płaskiego. [...] Następnie pacjentkę skierowano do centrum onkologicznego [...]. Lekarz kierujący oddziałem ginekologii onkologicznej odmówił przyjęcia pacjentki w wyznaczonym terminie. Lekarz ginekolog-onkolog napisał: „Ze względu na stan psychiczny pacjentki - schizofrenia paranoidalna i specyfikę oddziału istnieje zagrożenie dla pacjentek leczonych w oddziale" [...]. (PP1)

Chory obciążony trombofilią w przebiegu wrodzonej koagulopatii z mutacją genu czynnikia V typu Leiden, cukrzycą typu 2, przewlekłą obturacyjną chorobą płuc, przebytą w 2006 roku zatorowością płucną w przebiegu nawracającej zakrzepicy żył głębokich prawej kończyny dolnej. (PP3)

Objawy były czasowo ściśle powiązane z przygotowaniami do ślubu, a z powodu ich narastania kobieta w czwartym dniu po ślubie była hospitalizowana na oddziale całodobowym dużego szpitala psychiatrycznego (Szpital Tworkowski). (PSYCH3)

\section{(4b) Przebyte leczenie oraz jego efekty}

Zastosowane leczenie farmakologiczne [...] nie przyniosło oczekiwanych efektów. (PPK1)

Analiza dokumentacji medycznej wskazywała, że leki przeciwpsychotyczne były stosowane jako potencjalizacja leczenia przeciwdepresyjnego [...]. (PP2)

Zastosowano jednocześnie dwa leki normotymiczne (do węglanu litu dołączono lamotryginę) co tylko umiarkowanie wpłynęło na przebieg choroby. (PSYCH3)

\section{Aktualne leczenie}

\section{(5a) Przeprowadzone badania i ich wyniki}

W badaniu psychologicznym ogólny poziom funkcjonowania poznawczego badany metodą Wechslera określono jako bardzo wysoki, wyrażony kryterium liczbowym 135 . Wykonano również badanie CT głowy, które nie ujawniło odchyleń od stanu prawidłowego. (PPK5)

W szczegółowych testach: MMSE (Mini Mental State Examination; wynik nieskorygowany): 23 pkt; TRZ (Test Rysowania Zegara): wykonanie nieznacznie osłabione (błędy semantyczne) $(-,+,+)[\ldots]$. W badaniu psychiatrycznym chory był prawidłowo, wszechstronnie zorientowany, w kontakcie werbalnym logicznym, mowa była niewyraźna, nastrój z tendencją do obojętności. (PP3)

Podczas pierwszego wywiadu pacjentka kilkakrotnie wymiotowała treścią podbarwioną żółcią. [...] Gardło było zaczerwienione, na języku był biały nalot. [...] W wykonanych kilkakrotnie badaniach laboratoryjnych z krwi żylnej (tj. morfologia, gazometria) [...] oraz badaniu moczu nie stwierdzono istotnych odchyleń. (PP4)

\section{(5b) Diagnoza}

Rozpoznano zespół niespokojnych nóg oraz współistniejącą aksonalną neuropatię obu nerwów łydkowych. (PP5) 


\section{(5c) Leczenie (odnoszące się do opisywanego zaburzenia) i jego wynik}

Dawka ładunku elektrycznego została wstępnie ustalona. Szerokość impulsu, częstotliwość i natężenie były w trakcie wszystkich zabiegów takie same i wynosiły odpowiednio: 0,50 ms, 10-30 Hz, i 0,89-0,91 A. [...]. Pacjentka otrzymywała klorazepat domięśniowo, jednak nie odnotowano poprawy. [...] Po 14 dniach od ostatniego zabiegu EW i 11 dniach leczenia olanzapiną uzyskano poprawę stanu psychicznego, zaobserwowano ustąpienie urojeń [...]. (PP2)

Pacjentka została poddana zabiegom elektrowstrząsowym (wykonano łącznie 10 zabiegów). Po pierwszym zabiegu przestała samodzielnie jeść, po kolejnym w trakcie snu krzyczała, wyrywała sobie wkłucie dożylne [...]. (PSYCH4)

\section{(5d) Stan przy wypisie oraz dalsze zalecenia}

Pacjentka została wypisana ze szpitala w stanie psychicznym wyrównanym. (PP2)

Kontynuowano leczenie pacjentki olanzapiną w dawce $15 \mathrm{mg} / \mathrm{d}$ przez kilka kolejnych miesięcy po wypisie ze szpitala. Stan psychiczny chorej w tym czasie pozostawał stabilny. (PP2)

Zalecono terapię gabapentyną w dawce $900 \mathrm{mg} / \mathrm{d}$, ropinirol w dawce $0,5 \mathrm{mg} / \mathrm{d}$, kontrolne badanie glikemii na czczo oraz rozszerzenie diagnostyki polineuropatii. W tym celu pacjentka została skierowana na oddział neurologiczny. (PP5)

\section{(5e) Dalsze zalecenia}

Po ustabilizowaniu się stanu psychicznego pacjentka została wypisana do domu z rozpoznaniem psychozy schizoafektywnej oraz zaleceniem kontynuowania farmako- i arteterapii. (PPK4)

Analizując historię bliźniąt, zadaliśmy sobie pytanie: w jakim celu rodzice zgłaszają się z dziećmi po rozpoznanie, a następnie podważają diagnozę i zmieniają ośrodek? (PPK2)

\section{Inne elementy}

\section{(6a) Określenie źródła wiadomości}

Z tego okresu pochodzą wybrane wypowiedzi pacjenta na temat jej problemów - spisane przez nią, gdy miała 14 lat, adresowane do lekarza prowadzącego i psychologa, a przekazane przez matkę. (PPK1)

Pacjentka $w$ trakcie leczenia epizodu depresji stworzyła jedną z prac plastycznych na zadany temat: „Narysuj postać w deszczu” [...]. Istotna jest kompozycja pracy. Postać została umieszczona w górnej połowie kartki, nie kończy się jednak w jej obrębie. [...] Postać nie ma stóp, co może wskazywać na poczucie braku ugruntowania, oparcia, stabilności. (PPK4)

Opis przebiegu choroby oparty został na szczególnym wywiadzie od pacjentki i jej rodziny, dostępnej dokumentacji medycznej z 48 lat leczenia szpitalnego, ambulatoryjnego 
i opieki środowiskowej. Analizy obrazu chorobowego dokonano z uwzględnieniem aktualnie proponowanych w literaturze teorii etapów przebiegu choroby afektywnej dwubiegunowej ${ }^{8}$. (PSYCH3)

Przytoczono poniżej dwa fragmenty wypowiedzi pacjenta, pierwszy z nich został zanotowany w trakcie wizyty, kiedy zgłosił się do leczenia, drugi stanowi odpowiedź na pytanie o samopoczucie i dostrzegane zmiany (jak czuł się przed rozpoczęciem leczenia, a jak czuje się obecnie, w styczniu 2016 roku). (PSYCH5)

\section{(6b) Osoba terapeuty}

Autor niniejszej pracy był bardzo poruszony konsultacjami z Panem B. Próbował wczuć się w ten wyidealizowany stan bezruchu, jaki opisywał pacjent. [...] Niepokoiło go dążenie pacjenta do braku zależności i satysfakcja, z jaką opowiadał o tym, jak udawało mu się zrywać kontakty z osobami, którym na kontakcie z nim zależało. [...] Nadzieję wzbudzało zainteresowanie pacjenta Panią A. i jego zdolność do otwartej rozmowy z nią [...]. Autor tego opisu również doświadczał nie tylko troski o pacjenta, ale także był nim zainteresowany i czuł możliwość głębokiego zaangażowania w próbę pomocy Panu $\mathrm{B}$. (PSYCH1)

\section{(6c) Sposób analizy przez terapeutę}

Zdecydował się [psychoanalityk, autor pracy] zatem zaproponować Panu B. psychoanalizę, z sesjami 4 razy w tygodniu. [...] Na przykład na jednej z sesji pacjent opowiadał, jak jadąc na sesję pociągiem, słyszał rozmowę pewnego - jak to się wyraził - idioty, który dzwonił do bliskiej osoby i prosił ją, by nie wychodziła dzisiaj z domu, bo ma złe przeczucia. Pan B. oczywiście natrząsał się z tego mężczyzny [...], ale pod koniec posmutniał i powiedział, że zdał sobie sprawę, że ten mężczyzna, być może w głupi sposób, ale troszczy się o swoją rozmówczynię. Psychoanalityk zinterpretował to jako wyraz zauważenia jego troski [...]. (PSYCH1)

W sekcji Opis przypadku i w całych opisach przypadków z dziedziny psychologii i psychiatrii ogólnie, na uwagę zasługuje także pierwiastek narracyjności, który jest obecny w tych typach tekstów. W ww. opisach wyróżnić można trzy rodzaje narracji:

(1) Bardzo emocjonalna relacja ze słów pacjenta, która przytaczana jest przez lekarza, często jako długie fragmenty, czasami tylko jako pojedyncze wyrażenia.

„W główce występuje także kolizja dwóch osobowości Julci - tej anioła, która jest związana z głosikiem, odruchami, którą Julcia udostępnia w domku, i tej osobowości, która jest szatankiem, czyli wiąże się z wypiętym przodzikiem, napiętymi i naprężonymi pleckami [...] i oschłym głosikiem z użyciem nieskrępowanych słówek, bez zdrobnień"9. (PPK1)

Pierwsze wspomnienie mężczyzny dotyczy chwili wypadku: „pamiętam, jak jechaliśmy samochodem osobowym i uderzyła w nasz bok naczepa tira jadącego z przeciwka, potem ja (moja dusza), taki lekki, wyciągałem ręce w stronę szyby i wyszedłem z samochodu".

\footnotetext{
${ }^{8} \mathrm{~W}$ pracy element ten stanowi odrębną, jednak krótka sekcję Materiał i metody i poprzedza opis pacjenta.

${ }^{9}$ Sposób prowadzenia narracji (tj. zdrobnienia itp.) charakterystyczny jest dla zespołu Aspergera (zob. PPK1 - A. Mazur i I. Chojnowska-Ćwiąkała 2016).
} 
[...] „Po obejrzeniu akcji ratunkowej z perspektywy świadka znalazłem się w szpitalu, do którego nagle się przeniosłem, widziałem tam samego siebie leżącego na łóżku z czerwonym podkoszulku, pomyślałem, że to dziwne, bo miałem na sobie granatową, i wówczas zdałem sobie sprawę, że to krew - że jestem cały we krwi”. (PPK3)

Pan B. częściej powtarzał, że „z całą pewnością nic nie zrobi, by zmienić swoją sytuację”, a także, iż ,jest beznadziejny”. O owej beznadziejności świadczyło na przykład to, że jak to ująl - „ma od tej dziewczyny wyższą pozycję, zarabia siedem razy więcej. Można powiedzieć - idealny kandydat na męża, a nawet nie potrafi się z nią umówić”. (PSYCH1)

\section{(2) Narracja czlonków rodziny o pacjencie ${ }^{10}$}

Zdaniem rodziców ich synowie mają kłopot w kontaktach z rówieśnikami. [...],„Niczym się nie interesują" - stwierdza mama, później jednak rodzice doprecyzowują, iż chłopcy lubią grać w gry komputerowe i czytać literaturę fantasty. (PPK2)

\section{(3) Narracja terapeuty o pacjencie, sesjach terapeutycznych itp. ${ }^{11}$}

Terapeuta zdecydował, że nie będzie interpretować jego [pacjenta] wewnętrznej sytuacji, która doprowadziła do decyzji o zerwaniu. [...] To się częściowo udało i po kilku sesjach po swojej decyzji, Pan B zakończył analizę. Pozostawił terapeutę z uczuciem żałoby i lękiem o dalsze jego losy ${ }^{12}$. (PSYCH1)

Kolejnym elementem zarówno tradycyjnego opisu przypadku, jaki i opisów przychiatryczno-psychologicznych jest Dyskusja, która realizuje krok 9, tj. Prezentacje ogólnych wyników badań poprzez (ae) powtórzenie tła omawianego problemu; (af) powtórzenie znaczenia problemu; (ag) określenie kluczowych czynników, które wskazują na daną chorobę oraz (ah) ogólne wskazówki diagnostyczno-kliniczne. Krok 10 - Omówienie wyników wtasnych to (ai) podsumowanie przedstawionego przypadku, (aj) porównanie uzyskanych wyników z literaturą i innymi badaniami, (ak) wskazanie na kierunek dalszych badań lub sposób postępowania przy takich samych lub podobnych przypadkach, (al) możliwe trudności diagnostyczno-kliniczne przy takich przypadkach.

Jak widać na poniższych przykładach, w obu dziedzinach tj. kliniczno-chirurgicznych oraz w psychiatrii i psychologii, sekcja Dyskusja zawiera podobne zakresy informacji, dlatego zostaną one przedstawione (podobnie jak powyżej Wstęp) na zasadzie porównawczej.

(ae) U kobiet leczonych TKI zaleca się skuteczną antykoncepcję, a planowe zajście w ciążę powinno nastąpić po odstawieniu TKI. Zaprzestanie leczenia TKI wiąże się z ryzykiem nawrotu białaczki, dlatego sugeruje się, aby kobiety planujące ciążę leczono TKI do osiągnięcia co najmniej DMR przez minimum kolejne 2 lata. (HM2)

$* * *$

(ae) W przedstawionej przez J. Austin pracy doktorskiej [18] wskazuje ona na trudności w różnicowaniu zaburzeń dysocjacyjnych, w których objawy mogą przypominać te występujące w schizofrenii oraz innych psychozach. (PSYCH4)

${ }^{10}$ Zob. też przykład z punktu (2e) powyżej.

${ }^{11}$ Zob. też przykład z punktu (6b) powyżej.

${ }^{12} \mathrm{~W}$ tej pracy narracja występuje w 3 os. liczby pojedynczej. 
Aktualnie podstawową grupą lekową zalecaną w leczeniu RLS są leki dopaminergiczne [...]. Niestety, używane w długoterminowym leczeniu RLS leki dopaminergiczne w ciągu średnio 2,7 +/- 2,4-letniej farmakoterapii [9] powodują znaczące $\mathrm{w}$ procesie terapeutycznym zjawisko augmentacji. [...] (PP5)

(af) Ceruminous adenocarcinoma to rzadko występujący nowotwór złośliwy, rozwijający się z gruczołów woskowinowych obecnych w przewodzie słuchowym zewnętrznym [13]. Nie daje charakterystycznych objawów. (PPO1)

(af) Przypadek pani M. stanowił dla nas trudność diagnostyczną, Zaburzenia dysocjacyjne zaczynają się w dzieciństwie, często są mylne diagnozowane i przez to nieodpowiednio leczone. (PSYCH4)

(ag) W swym obrazie klinicznym może się objawiać cechami ostrego zespołu wieńcowego (ACS, acute coronary syndrome) z ostrą niewydolnością krążenia. Rozpoznania tego dokonuje się u 1-2\% pacjentów, u których pierwotnie rozpoznano ACS [1]. (CSN2)

$* * *$

(ag) W typowych rysunkach osób z rozpoznaniem depresji charakterystyczna są niepewna kreska, często przerywana, postaci pomniejszone [...], w tle mogą pojawiać się atrybuty przemijania [...]. (PPK4)

(ah) Badania obrazowe są konieczne przed leczeniem operacyjnym oraz użyteczne podczas diagnostyki. Tomografia komputerowa ukazuje rozmiar i lokalizację guza, cechy modelowania lub nacieku i destrukcji struktur sąsiednich, zwłaszcza kostnych. (PPO2) $* * *$

(ah) Leczeniem pierwszego wyboru w schizofrenii katatonicznej jest stosowanie benzodiazepin: lorazepam w dawce 1-2 mg co 4-12 godzin [4]. (PSYCH4)

(ai) U opisanej pacjentki ustalono rozpoznanie CML w okresie transformacji blastycznej. W chwili rozpoznania obraz hematologiczny był nietypowy, z leukopenią, znaczną nadpłytkowością i zwiększonym odsetkiem blastów w szpiku. (HM2)

(ai) U niespełna 18-letniej pacjentki, z objawami kolejnego epizodu depresji w przebiegu CHAD, stwierdzono w trakcie analizy jednej z prac wskaźniki emocjonalne zaburzeń paranoidalnych o treści wielkościowej [...]. (PPK4)

Zgodnie z tymi opiniami w pracy przedstawiono przypadki leczenia dwóch osób - pacjentki z depresją i łuszczycowym zapaleniem stawów, u której pełniejszy niż w przypadku stosowania leku z grupy SSRI stopień poprawy, dotyczący zarówno objawów depresji, jak i objawów bólowych uzyskano w trakcie podawania duloksetyny [...]. (PSYCH2)

\section{Podsumowanie}

W niniejszym cyklu prac omówiono zagadnienie opisów przypadków medycznych z zakresu psychiatrii i psychologii na tle całego mikrogatunku - opisów przypadków w ogóle. W pierwszej części cyklu przedstawiono szerokie tło teoretyczne. Autorki zwróciły uwagę na czynnik narracyjny, który ma duże znaczenie w całym procesie 
leczenia pacjenta (pełni funkcję terapeutyczną). Omówiono tu również budowę i zalecenia dotyczące tworzenia psychiatrycznych opisów przypadków na tle tych tradycyjnych, jak również podkreślono znaczenie i charakterystykę konceptualizacji (sformułowania) przypadku jako jednego z głównych elementów psychiatrycznego opisu przypadku. To właśnie ten pierwiastek narracyjny i konceptualizacja przypadku wyróżniają opisy z zakresu psychiatrii i psychologii od opisów z dziedzin kliniczno-chirurgicznych.

Konkludując rozważania teoretyczno-empiryczne zauważyć należy, iż opisy przypadków medycznych z psychiatrii i psychologii, podobne jak tradycyjne opisy z dziedzin kliniczno-diagnostycznych, noszą cechy mikrogatunku, jednakże ich struktura i wzorce prowadzenia wywodu różnią się w zależności od opisywanego zagadnienia. Oba typy tekstów składają się z Wstępu, Opisu przypadku (w psychiatrycznych opisach jest on często podzielony na podsekcje), Omówienia (Dyskusji) i Wniosków. Zakres podawanych informacji jest również podobny, jednakże sam opis pacjenta i skupienie się na nim są bardziej rozwinięte w psychiatrycznych opisach, niż tych tradycyjnych. Świadczyć o tym mogą słowa H. Nowell-Smith (1995), która stwierdza iż „medyczne przypadki są opowieściami nie o bólu i strachu ale o medycznej interwencji, a głównymi postaciami są lekarze, instrumenty i organy" (1995: 64; tłum. M. Murawska 2014: 87). Opisy psychiatryczne to właśnie te opowieści o bólu, strachu, silnych emocjach, bezsilności pacjenta, a interwencja medyczna stanowi tylko tło do rozważań. Główną postacią jest tu pacjent, a instrumenty i organy są tylko dodatkiem do budowania całościowego obrazu leczenia.

\section{Bibliografia}

Murawska, M. (2014), Spójność tekstu specjalistycznego a obraz pacjenta w medycznym opisie przypadku, (w:) M. Kornacka (red.), Studi@ Naukowe 23. Spójność tekstu specjalistycznego. Warszawa, 80-89.

Nowell-Smith, H. (1995), Nineteenth-century Narrative Case Histories: An Inquiry into Stylistics and History, (w:) „CBMH/BCHM” 12, 47-67.

Nwogu, K. (1990), Discourse Variation in Medical Texts: Schema, Theme and Cohesion on Professional and Journalistic Accounts. Nottingham.

Nwogu, K. (1991), Structure of Science Popularizations: A Genre-analysis Approach to the Schema of Popularized Medical Texts, (w:) „English for Specific Purposes” $10(2), 111-123$.

Nwogu, K. (1997), The Medical Research Paper: Structure and Functions, (w:) „English for Specific Purposes" 16(2), 119-138.

Swales, J. (1990), Genre Analysis: English in Academic and Research Settings. Cambridge.

Virués-Ortega, J./ R. Moreno-Rodriguez (2008), Guidelines for Clinical Case Reports in Behavioural Clinical Psychology, (w:) „International Journal of Clinical and Health Psychology" 8(3), 765-777.

Zabielska, M./ M. Żelazowska (2016), Spójność tekstu specjalistycznego a obraz pacjenta w medycznym opisie przypadku (kontynuacja badania), (w:) M. Górnicz/ 
M. Kornacka (red.), Studi@ Naukowe 34. Spójność tekstu specjalistycznego (2). Warszawa, 112-124.

Żelazowska-Sobczyk, M./ M. Zabielska (2018), Tytuły w polskojęzycznych opisach przypadków medycznych: wstęp do badań, (w:) „Applied Linguistics Papers” 25(2), 183-202.

Żelazowska-Sobczyk, M. (2019), Polskie i angielski opisy przypadków medycznych wujęciu kontrastywnym. (Studi@ Naukowe 43). Warszawa.

\section{Material źródłowy}

\section{Grupa 1}

PP1 - Tylec, A. i in. (2018), Trudności drugorzędowej profilaktyki raka szyjki macicy u kobiet leczonych z powodu schizofrenii paranoidalnej - opis przypadku, (w:) „Psychiatria Polska” 52(2), 251-259.

PP2 - Antosik-Wójcińska, A./ M. Chojnacka/ Ł. Święcicki (2017), Objawy psychotyczne jako powiktanie przebiegu leczenia elektrowstrzasowego - opis przypadku, (w:) „Psychiatria Polska” 51(1), 23-27.

PP3 - Objawy neurologiczne i neuropsychologiczne w przewlektej postaci choroby Whipple'a - opis przypadku, (w:) „Psychiatria Polska” 51(5), 953-961.

PP4 - Paszyńska, E. i in. (2016), Zmiany w jamie ustnej w przebiegu intensywnych wymiotów u pacjentki z zaburzeniem wegetatywnym występującym pod postacia somatyczna - opis przypadku, (w:) „Psychiatria Polska” 50(3), 521-531.

PP5 - Narowska, D. i in. (2015), Czeste problemy w leczeniu zespotu niespokojnych nóg - opis przypadku i przegląd piśmiennictwa, (w:) „Psychiatria Polska” 49(5), 921-930.

PPK1 - Mazur, A./ I. Chojnowska-Ćwiąkała (2016), Zespót Aspergera u 19-letniej kobiety ze szczególnym uwzględnieniem okresu adolescencji - opis przypadku, (w:) „Psychiatria i Psychologia Kliniczna” 16(1), 38-46.

PPK2 - Łucka, I. i in. (2014), Zespót Aspergera u bliźniąt - dylematy diagnostyczne i terapeutyczne. Opis przypadku, (w:) „Psychiatria i Psychologia Kliniczna” 14(1), 55-60.

PPK3 - Pawełczyk, A. i in. (2012), Zjawiska autoskopiczne - przeglad badań i opis przypadku, (w:) ,Psychiatria i Psychologia Kliniczna” 12(3), 193-198.

PPK4 - Gmitrowicz, A./ M. Kozińska-Lipińska/ M. Grancow-Grabka (2012), Diagnostyczna funkcja arteterapii na oddziale psychiatrycznym dla młodzieży - opis przypadku, (w:) „Psychiatria i Psychologia Kliniczna” 12(3), 199-202.

PPK5 - Józefowicz, O. i in. (2011), Obłęd we dwoje. Opis przypadku, (w:) „Psychiatria i Psychologia Kliniczna" 11(3), 194-196.

PSYCH1 - Srebrny, K. (2018), O nieudanej próbie zmagań z organizacja patologiczna, (w:) „Psychiatria” 15(3), 165-172.

PSYCH2 - Murawiec, S. (2017), Duloksetyna w leczeniu depresji z bólem fizycznym i psychicznym, (w:) „Psychiatria” 14(3), 144-149.

PSYCH3 - Sokół-Szawłowska, M. (2015), Opis przypadku 72-letniej pacjentki 
w kontekście etapów przebiegu choroby afektywnej dwubiegunowej oraz form polskiej opieki psychiatrycznej trwającej od prawie pół wieku, (w:) „Psychiatria” 12(3), 195-200.

PSYCH4 - Świerkosz, A. i in. (2015), Zaburzenia dysocjacyjne czy psychotyczne? Stupor u 23-letniej pacjentki, (w:) „Psychiatria” 12(3), 201-207.

PSYCH5 - Murawiec, S. (2016), Pregabalina - opis przypadku w kontekście wiedzy na temat działania leku i praktyczne wskazówki stosowania, (w:) „Psychiatria” 13(1), 17-24.

\section{Grupa 2}

CSN1 - Zamelska, U. i in. (2018), Zator tętnicy środkowej siatkówki jako pierwsza manifestacja kliniczna w postaci powikłania zatorowo-zakrzepowego jednopłatkowej zastawki aortalnej - opis przypadku, (w:) „Choroby Serca i Naczyń” 15(4), 245-250.

CSN2 - Młodzianowski, A.T. (2018), Nawracająca kardiomiopatia takotsubo wywotana zaostrzeniem przewlektym obturacyjnej choroby płuc i beta-mimetykami, (w:) „Choroby Serca i Naczyń” 15(3), 177-180.

FC1 - Michalska, A. i in. (2018), Nadciśnienie tętnicze w okresie laktacji-czy zawsze należy leczyć?, (w:) „Folia Cardiologica” 13(2), 169-172.

FC2 - Kutek, B./ J. Kusa (2018), Kardiomiopatia takotubo u dziecka - opis przypadku, (w:) „Folia Cardiologica” 13(3), 264-268.

HM1 - Szypuła-Perkosz, I. i in. (2017), Skuteczna chemioterapia indukujaco-konsolidujaca u 20-letniej chorej na ostra białaczke promielocytowa niewyrażajacej zgody na przetoczenia preparatów krwiopochodnych z powodu przekonań religijnych, (w:) „Hematologia” 8(2), 152-158.

HM2 - Gołos, A. i in. (2017), Wspótistnienie dyskrazji komórek plazmatycznych zespołu mielodysplastycznego - opisy przypadków i przegląd piśmiennictwa, (w:) „Hematologia” 8(2), 144-151.

NA1 - Skarżyński, H./ K. Osińska/ P.H. Skarżyński (2018), Leczenie niedostuchu za pomoca implantu ślimakowego u pacjenta z zespołem MELAS, (w:) „Nowa Audiofonologia" 7(4), 61-65.

NA2 - Dziendziel, B. i in. (2018), Trudności $i$ wyzwania $w$ leczeniu niedostuchu u dziecka z zespotem Kostmanna - opis przypadku, (w:) „Nowa Audiofonologia” 7(3), 73-78.

PPO1 - Kłodawska, A./ K. Amernik/ E. Jaworowska (2018), Rzadki nowotwór przewodu stuchowego wywodzacy się z gruczołów woskowinowych - opis przypadku, (w:) „Polski Przegląd Otorynolaryngologiczny” 7(3), 32-36.

PPO2 - Sroka, P./ S. Okła (2018), Olbrzymi gruczolak wielopostaciowy nosa i zatok przynosowych, (w:) „Polski Przegląd Otorynolaryngologiczny” 7(3), 26-31. 